\section{Effects of Enhanced APG Surfactant on Leaching and Wettability of Six Bark Substrates}

\author{
Michael W. Olszewski ${ }^{1,3}$, Samara J. Danan ${ }^{1}$, and Thomas J. Boerth ${ }^{2}$
}

ADDITIONAL INDEX WORDs. wetting agent, nursery mixes, alkyl phenol ethoxylate, polyglucoside, block co-polymer

SUMMARY. Alkyl phenol ethoxylate (APE) surfactants are used in horticultural substrates but are considered nonbiodegradable, whereas others such as alkyl polyglucoside (APG) are derived from biodegradable sugar compounds. APE reduced total porosity (TP), container capacity (CC), and aeration porosity (AP) whereas APG with polyalkylene oxide block copolymer surfactant (APG/BLK) increased TP, CC, and AP for some substrates but other substrates remained unaffected by either surfactant. We determined substrate leaching fraction (LF) and wettability rating (WR) after drenches of 0.003 to $0.2 \mathrm{~mL} \cdot \mathrm{L}^{-1}$ APG/BLK for six bark substrates for three wetting cycles. After the third wetting cycle, five substrates had reduced LF and increased WR. Drenches of $0.2 \mathrm{~mL} \cdot \mathrm{L}^{-1} \mathrm{APE}$ or APG/BLK for three wetting cycles indicated that APE was more efficacious than APG/BLK for reducing $L F$ or increasing WR. APE was determined to be an effective surfactant for difficult-to-wet substrates, but drenching sometimes reduced TP. No reductions in TP were noted when using APG/BLK. Drenching rates of $0.003-0.2 \mathrm{~mL} \cdot \mathrm{L}^{-1}$ APG/BLK for three successive wetting cycles reduced LF and increased WR for most substrates, indicating potential usage for some horticultural applications.

S urfactants increase wettability of pine bark and may be required in coarse substrates to enhance lateral movement of water and reduce infiltration rate through a container (Bilderback, 1993). Cid-Ballarin et al. (1998) hypothesized that surfactants enhance lateral water movement by increasing the number of small pores that water penetrates. This effect was most noticeable after desiccation of substrate and subsequent rehydration. A wide spectrum of surfactants exist for various applications and selection criteria, including wetting ability, foaming formation/defoaming characteristics, cosynergistic interactions, and other properties (Karsa, 2006).

Polyalkylene oxide block copolymers (BLKs) and alkyl phenol ethoxylates (APEs) are synthetic surfactants frequently used in professional horticultural substrates (Templeton, 1999; Yelanich and Vetanovetz, 2004). The UK restricts the use of APEs and Switzerland has banned them (Hepworth, 2006). Incomplete bacterial biodegradation of APEs has been documented (White, 1993). Wide usage of APEs in the United

${ }^{1}$ Department of Landscape Architecture and Horticulture, Temple University Ambler College, Ambler, PA 19002-3999

${ }^{2}$ Aquatrols Corporation of America, 1273 Imperial Way, Paulsboro, NJ 08066

${ }^{3}$ Corresponding author. E-mail: olszewsk@temple.edu.
States has resulted in detrimental accumulation in the Cuyahoga River of Ohio (Rice et al., 2003). BLK surfactants are widely used in many industries, but products are limited in abilities because often there is a tradeoff between desired foaming characteristic, biodegradability, and toxicity (Hepworth, 2006). Organic or naturally occurring surfactants generally are not accepted by professional horticulturists because of lack of efficacy data and because they potentially serve as a nutrient source for microbes (Czarnota and Thomas, 2006). Alkyl polyglucosides (APGs) are synthetic surfactants derived from glucose and palm or coconut oil-based alcohols (Hepworth, 2006) and are considered less harmful to the environment than other surfactants with some current applications as agronomic adjuvants (Czarnota and Thomas, 2006).

There appears to be little or no literature concerning APG-based surfactants in horticultural substrates. BLK surfactants alone traditionally have been poor alternatives to highquality APEs, but an alternative may be a synergistic blend of APG/BLK. The objective of this experiment was to determine the efficacy of an APG/ BLK blend in six proprietary barkbased nursery substrates and to evaluate it as a potential replacement of APEs.

\section{Materials and methods}

Six proprietary professional bark substrates (S-1 through S-6) containing no surfactant were used in this study. Formulated surfactants of $51 \%$ APG/BLK plus $49 \%$ inert (wt:wt) and $99 \%$ APE plus $1 \%$ inert (wt:wt) were obtained from Aquatrols Corporation of America (Paulsboro, NJ).

Physical properties of substrates were determined with and without $1.0 \mathrm{~mL} \cdot \mathrm{L}^{-1} \mathrm{APG} / \mathrm{BLK}$ or APE. To determine substrate physical properties, 3.5-inch-tall $\times 4$-inch-diameter pots were lined with a thin plastic sheet. Pots were filled with $400 \mathrm{~cm}^{3}$ equaling $115,70,140,210,330$, and $190 \mathrm{~g}$ of S-1, S-2, S-3, S-4, S-5, and S-6, respectively, at 30\% substrate moisture (by weight). This substrate moisture content was chosen because preliminary testing indicated water repellency at this particular stage. Substrate moisture was determined based on water weight loss at 110 ${ }^{\circ} \mathrm{C}$ using a moisture analyzer (IR200; Denver Instrument, Denver, $\mathrm{CO})$. Total porosity (TP) percentage was determined gravimetrically as the weight of water to completely saturate $400 \mathrm{~cm}^{3}$ of substrate. Leachate then was allowed to drain by piercing the plastic through the four drainage holes. Container capacity (CC) and aeration porosity (AP) were determined gravimetrically similar to Pill et al. (1995). CC equaled the amount of water retained after drainage divided by $400 \mathrm{~cm}^{3}$ followed by

\begin{tabular}{lllc}
\hline $\begin{array}{l}\text { Units } \\
\text { To convert U.S. to SI, } \\
\text { multiply by }\end{array}$ & U.S. unit & SI unit & $\begin{array}{l}\text { To convert SI to U.S., } \\
\text { multiply by }\end{array}$ \\
\hline 29.5735 & $\mathrm{fl} \mathrm{oz}$ & $\mathrm{mL}$ & 0.0338 \\
2.54 & inch $(\mathrm{es})$ & $\mathrm{cm}$ & 0.3937 \\
25.4 & inch $(\mathrm{es})$ & $\mathrm{mm}$ & 0.0394 \\
16.3871 & inch & $\mathrm{cm}^{3}$ & 0.0610 \\
28.3495 & $\mathrm{oz}$ & $\mathrm{g}$ & 0.0353 \\
0.001 & $\mathrm{ppm}$ & $\mathrm{mL} \cdot \mathrm{L}^{-1}$ & 1000 \\
$\left({ }^{\circ} \mathrm{F}-32\right) \div 1.8$ & ${ }^{\circ} \mathrm{F}$ & ${ }^{\circ} \mathrm{C}$ & $\left(1.8 \times{ }^{\circ} \mathrm{C}\right)+32$
\end{tabular}


multiplication by 100 and AP equaled TP percentage minus CC. Percentage of fine particles was determined by adding $50 \mathrm{~g}$ of air-dried substrate to a U.S. Standard Sieve No. 40 (pore diameter $=0.42 \mathrm{~mm}$ ), handshaking in a rotational manner for 5 min, and calculating the percentage (by weight) of materials passing through the sieve.

Surfactant efficacy in substrates was determined by methods similar to Walden et al. (2000). Pots were filled as previously stated. Substrate was irrigated with $300 \mathrm{~mL}$ of distilled water containing 0 (control), 0.003 , 0.006 (recommended weekly application rate), or $0.012 \mathrm{~mL} \cdot \mathrm{L}^{-1} \mathrm{APG} /$ BLK. After drainage, leaching fraction (LF) was calculated as the percentage volume of leachate divided by $300 \mathrm{~mL}$ applied. Visible wetting of substrate was evaluated by wettability rating (WR; Fig. 1). Irrigated substrates were dried back at laboratory conditions $\left(20{ }^{\circ} \mathrm{C}, 44 \%\right.$ relative humidity) to original moisture content so that we could determine the cumulative effect of three surfactant applications. Subsequent evaluations were similar to the first wetting. Each substrate had three wetting cycles with distilled water or APG/BLK treatment added at each event.

APG/BLK was compared with APE using methods similar to the previously described experiment. Pots were filled as previously stated and substrate was irrigated with $300 \mathrm{~mL}$ of distilled water containing $0.2 \mathrm{~mL} \cdot \mathrm{L}^{-1}$ APG/BLK or APE. After drainage, $\mathrm{LF}$ and WR were determined. Irrigated substrates were dried back to original moisture content and were evaluated similarly to the first wetting. Each substrate had three wetting cycles with APG/BLK or APE added at each event.

Experiments were designed as completely randomized blocks with five replications of each treatment. All data were subjected to analysis of variance. Percentage data were arc sine square root transformed [arc sine $\sqrt{ } \%$ (Gomez and Gomez, 1984)] and means were separated by Fisher's protected least significant difference (LSD) at $P \leq 0.05$.

\section{Results and discussion}

FP, TP, CC, AND AP. Substrates S-2 and S-4 had the highest percentage of fine particles (FP), whereas $S-1$ and S-5 had the lowest percentage of FP (Table 1). APE-treated S-2 had reduced CC, whereas S-4 had reduced $\mathrm{TP}$, and APE-treated S-I had reduced TP and AP compared with the control. S-5 and S-6 physical properties were unaffected by APG/
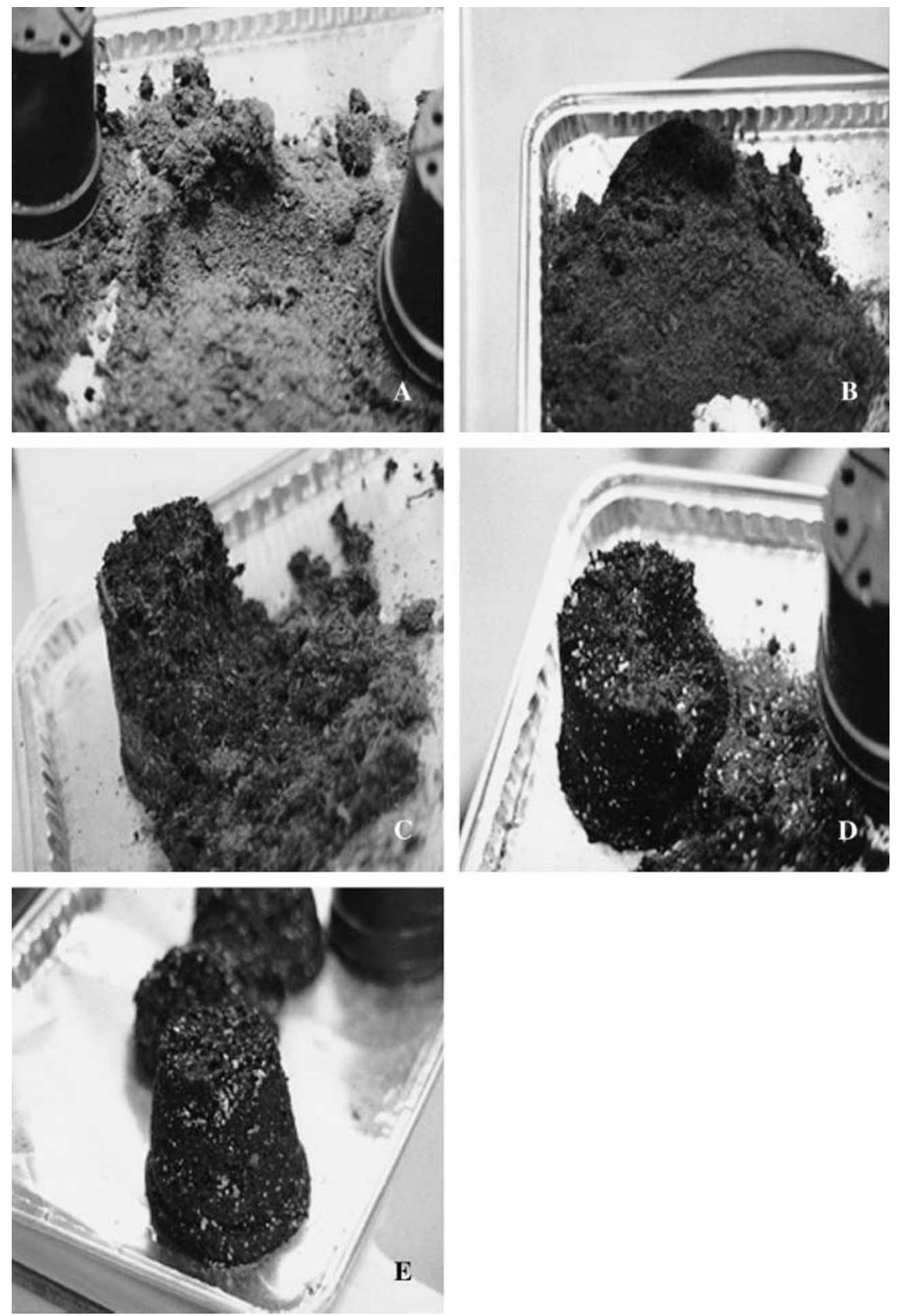

Fig. 1. Pots containing irrigated substrate were inverted and the substrate was visually evaluated for wettability rating (WR): (A) WR $1=$ less than $10 \%$ of substrate conglomerated with most of substrate unwetted; (B) WR $2=$ one-third of substrate conglomerated with a majority of substrate unwetted; (C) WR 3 = about one-half of substrate conglomerated and about one-half of substrate unwetted; (D) WR $4=$ two-thirds of substrate conglomerated with a majority of substrate wetted; and (E) WR 5 = maximum conglomeration of substrate with virtually all of substrate wetted. 
Table 1. Percentage of fine particles (FP) and the effect of control (distilled water) or $1.0 \mathrm{~mL} \cdot \mathrm{L}^{-1}(1000 \mathrm{ppm})$ alkyl polyglucoside and polyalkylene block copolymer (APG/BLK) or alkyl phenol ethoxylate (APE) additions on total porosity (TP), container capacity (CC), and aeration porosity (AP) for six bark substrates. ${ }^{\mathrm{z}}$

\begin{tabular}{|c|c|c|c|c|c|}
\hline Substrate $^{y}$ & Surfactant & $\begin{array}{c}\text { FP } \\
(\% \pm S D)^{x}\end{array}$ & $\begin{array}{c}\text { TP } \\
{[\%(\text { deg. })]^{w}}\end{array}$ & $\begin{array}{c}\text { CC } \\
[\% \text { (deg. })]\end{array}$ & $\begin{array}{c}\mathrm{AP} \\
{[\%(\mathrm{deg} .)]}\end{array}$ \\
\hline \multirow[t]{4}{*}{$S-1$} & - & $25 \pm 3$ & - & - & - \\
\hline & Control & - & $91(73) a^{v}$ & $74(60) a b$ & $17(24) \mathrm{a}$ \\
\hline & $\mathrm{APG} / \mathrm{BLK}$ & 一 & $91(73) a$ & $77(61) a$ & $14(22) a b$ \\
\hline & $\mathrm{APE}$ & - & $86(66) b$ & $73(59) \mathrm{b}$ & $13(21) b$ \\
\hline \multirow[t]{4}{*}{ S-2 } & & $43 \pm 4$ & - & - & - \\
\hline & Control & - & $88(70) a b$ & $61(51) a$ & $27(32) a$ \\
\hline & APG/BLK & - & $91(73)$ a & $55(48) a b$ & $37(37) \mathrm{a}$ \\
\hline & $\mathrm{APE}$ & - & $83(66) b$ & $50(45) \mathrm{b}$ & $34(35) \mathrm{a}$ \\
\hline \multirow[t]{4}{*}{$S-3$} & & $28 \pm 4$ & - & - & - \\
\hline & Control & - & $76(61) b$ & $61(51) a$ & $15(23) \mathrm{b}$ \\
\hline & $\mathrm{APG} / \mathrm{BLK}$ & - & $89(72)$ a & $59(50)$ a & $30(33)$ a \\
\hline & $\mathrm{APE}$ & - & $84(67) a b$ & $59(50)$ a & $25(30) a b$ \\
\hline \multirow[t]{4}{*}{$S-4$} & & $42 \pm 4$ & - & - & - \\
\hline & Control & - & $74(60)$ a & $48(44) \mathrm{a}$ & $26(31) a$ \\
\hline & APG/BLK & - & $70(57) a b$ & $53(47)$ a & $17(24) \mathrm{a}$ \\
\hline & $\mathrm{APE}$ & - & $68(56) \mathrm{b}$ & $48(44) \mathrm{a}$ & $20(26) \mathrm{a}$ \\
\hline \multirow[t]{4}{*}{ S-5 } & & $25 \pm 2$ & - & - & - \\
\hline & Control & - & $65(54) \mathrm{a}$ & $49(45) \mathrm{a}$ & $15(23) \mathrm{a}$ \\
\hline & $\mathrm{APG} / \mathrm{BLK}$ & - & $64(53) a$ & $48(44) \mathrm{a}$ & $16(24) \mathrm{a}$ \\
\hline & $\mathrm{APE}$ & - & $65(54) \mathrm{a}$ & $47(43) \mathrm{a}$ & $17(25) \mathrm{a}$ \\
\hline \multirow[t]{4}{*}{ S-6 } & & $36 \pm 4$ & - & - & - \\
\hline & Control & - & $89(71) a$ & $75(60) a b$ & $13(21) \mathrm{a}$ \\
\hline & $\mathrm{APG} / \mathrm{BLK}$ & - & $88(69)$ a & $74(59) \mathrm{b}$ & $13(22) \mathrm{a}$ \\
\hline & $\mathrm{APE}$ & - & $91(73) \mathrm{a}$ & $78(62) \mathrm{a}$ & $14(22) \mathrm{a}$ \\
\hline
\end{tabular}

${ }^{2} \mathrm{TP}, \mathrm{CC}$, and AP determined for $400 \mathrm{~cm}^{3}\left(24.4\right.$ inch $\left.^{3}\right)$ in 3.5 -inch-tall $\times 4.0$-inch-diameter $(8.89 \times 10.16-\mathrm{cm})$ pots.

${ }^{y}$ Bark components for substrate (S) 1 through 6 were balsam fir (Abies balsamea) and spruce (Picea spp.; S-1 and S-6); redwood (Sequoia sempervirens; S-2); fir (Abies spp.), pine (Pinus spp.), and redwood, (S-3 and S-4); and fir, pine, and spruce (S-5)

xercentage of particle sizes less than $0.42 \mathrm{~mm}(0.017$ inches $) ; \mathrm{n}=5$.

${ }^{w}$ deg. $=$ angular transformation of percentage data $(\operatorname{arc} \operatorname{sine} \sqrt{ } \%)$.

"Mean separation among treatments by substrate indicated by a different letter at $P \leq \mathrm{g} 0.05$ using Fisher's protected least significant difference.

small pores preferentially and enhance water holding capacity; however, substrates containing a high percentage of FP did not have a higher CC when treated with APG/BLK or APE. Our data indicated that there was no specific effect of surfactants on water retention in substrates containing high or low percentages of FP. There were no AP differences between APG/BLK and APE. Blodgett et al. (1993) found that surfactant addition increased CC in a peat-based mix but not in a bark-based one. Likewise, Bilderback and Lotscheider (1997) concluded that surfactant additions had little effect on water or air concentrations in a pine bark substrate and that surfactant amendments were most effective under decreased irrigation regimes. Our results indicate that effects on physical properties can be affected by type of surfactant and substrate.

APG/BLK EFFICACY. Irrigation with APG/BLK reduced LF in $S-1$, S-3, S-4, S-5, and S-6 and increased WR for S-1, S-3, S-4, S-5, and S-6 after three wetting cycles, respectively (Table 2). APG/BLK was ineffective at increasing WR in $S-2$, and by the third wetting cycle, APG/ BLK-treated S-2 had increased LF, which is hypothesized to result from decreased water tension and hydrophobic substrate surfaces repelling the water and rapid leaching down container walls. Quadratic responses to surfactant rate after three wetting cycles seem to support this hypothesis. Thus, a higher rate of surfactant could potentially increase infiltration rate and increase LF. Significant water repellency commonly occurs in bark substrate at $<35 \%$ moisture content (by weight), and 1 to $5 \mathrm{~mL} \cdot \mathrm{L}^{-1}$ surfactant is necessary to increase water retention of bark substrate (Airhart et al., 1980). Our data indicated onethird of the substrates tested were adequately wetted using lower rates for three successive applications. Airhart et al. (1978a) found that maintaining minimum threshold moisture contents is required for bark to rehydrate. It was thought that proprietary substrates used here had different minimum threshold moisture contents because bark was not the only component of the mixes. It is hypothesized that low rates of surfactant are only effective when bark substrate is at or slightly less than this threshold.

APG/BLK vERSUS APE. Significant wetting cycle differences $(P$ $\leq 0.001$ ) illustrated the cumulative effect of successive $0.2 \mathrm{~mL} \cdot \mathrm{L}^{-1}$ surfactant drenches on substrate LF and WR (Table 3). The first wetting cycle in particular had higher LF and reduced WR compared with the second or third wetting cycles. After the third wetting cycle, there was no difference in WR between APG/ BLK and APE, except for S-3 and S-6, where APE had the higher WR. Interactions between surfactant type and wetting cycle indicated that APE, but not APG/BLK, was capable of wetting the most difficult-to-wet bark mixes S-3 and S-6. The WR for APE-treated S-3 after the third wetting cycle was 5.0 , whereas that for APG/BLK-treated was 4.0. The WR for APE-treated S- 6 after the third wetting cycle was 5.0 , whereas that for APG/BLK-treated was 3.0.

Although surfactant chemistry class affects wettability of bark substrates (Airhart et al., 1980), it remains unclear as to specific reasons for increased efficacy of APE compared with APG/BLK in bark substrates. Plant anatomical structures and hydrophobic plant cellular substances likely contribute to water repellency in bark (Airhart et al., 1978b). Most bark materials used in this study were blends of various species, therefore it was not possible to determine individual bark species' contribution to observed water repellency. The sole bark component of S-2 was redwood (Sequoia sempervirens), which did not wet using 0.003 to $0.012 \mathrm{~mL} \cdot \mathrm{L}^{-1} \mathrm{APG} / \mathrm{BLK}$ (Table 2), but had reduced LF and 
Table 2. Effects of alkyl polyglucoside/polyalkylene block copolymer (APG/BLK) surfactant on leaching fraction percentage (LF) and wettability rating (WR) for six bark substrates after $300 \mathrm{~mL}(10.14 \mathrm{fl} \mathrm{oz})$ drenches containing $0.003,0.006$, or $0.012 \mathrm{~mL} \cdot \mathrm{L}^{-1}(3,6$, and $12 \mathrm{ppm})$ APG/BLK and three wetting cycles. ${ }^{\mathrm{z}}$

\begin{tabular}{|c|c|c|c|c|c|c|c|c|c|c|c|c|c|}
\hline \multirow[b]{3}{*}{ Wetting cycle } & \multirow[b]{3}{*}{$\begin{array}{c}\text { APG/BLK } \\
\left(\mathrm{mL} \cdot \mathrm{L}^{-1}\right)\end{array}$} & \multicolumn{12}{|c|}{ Substrate $^{\mathrm{x}}$} \\
\hline & & \multicolumn{2}{|l|}{ S-1 } & \multicolumn{2}{|l|}{ S-2 } & \multicolumn{2}{|l|}{ S-3 } & \multicolumn{2}{|c|}{ S-4 } & \multicolumn{2}{|c|}{$S-5$} & \multicolumn{2}{|c|}{ S-6 } \\
\hline & & $\begin{array}{c}\text { LF } \\
{[\%(\text { deg. })]^{\mathrm{w}}} \\
\end{array}$ & $\mathbf{W R}^{\mathbf{v}}$ & $\begin{array}{c}\text { LF } \\
{[\%(\text { deg. })]}\end{array}$ & WR & $\begin{array}{c}\text { LF } \\
{[\%(\text { deg. })]}\end{array}$ & WR & $\begin{array}{c}\text { LF } \\
{[\%(\text { deg. })]}\end{array}$ & WR & $\begin{array}{c}\text { LF } \\
{[\%(\text { deg. })]}\end{array}$ & WR & $\begin{array}{c}\text { LF } \\
{[\%(\text { deg. })]}\end{array}$ & WR \\
\hline \multirow[t]{4}{*}{1} & 0.0 & $45(42)$ & 3.6 & $70(57)$ & 2.0 & $76(61)$ & 2.8 & $60(51)$ & 3.0 & $71(58)$ & 3.2 & $67(55)$ & 1.8 \\
\hline & 0.003 & $55(48)$ & 3.8 & $76(61)$ & 2.0 & $78(62)$ & 2.8 & $74(59)$ & 2.2 & $63(53)$ & 4.4 & $72(58)$ & 1.8 \\
\hline & 0.006 & $47(44)$ & 3.8 & $79(62)$ & 2.2 & $81(64)$ & 2.8 & $63(52)$ & 3.4 & $64(53)$ & 4.0 & $70(57)$ & 2.0 \\
\hline & 0.012 & $45(42)$ & 3.8 & $71(58)$ & 2.0 & $86(68)$ & 2.2 & $67(55)$ & 4.0 & $81(64)$ & 2.2 & $68(55)$ & 2.0 \\
\hline Significance & & (Ns) & NS & (Ns) & NS & $\left(\mathrm{L}^{* * *}\right)$ & $\mathrm{L}^{*}$ & (Ns) & $\mathrm{L}^{*}$ & $\left(\mathrm{Q}^{\star *}\right)$ & $\mathrm{Q}^{* * *}$ & (Ns) & NS \\
\hline \multirow[t]{4}{*}{2} & 0.0 & $34(35)$ & 3.6 & $65(54)$ & 3.0 & $63(52)$ & 2.4 & $56(48)$ & 2.8 & $72(58)$ & 1.8 & $84(66)$ & 1.0 \\
\hline & 0.003 & $44(41)$ & 4.2 & $81(65)$ & 2.0 & $68(56)$ & 2.4 & $73(58)$ & 2.0 & $61(51)$ & 3.4 & $78(62)$ & 2.0 \\
\hline & 0.006 & $22(28)$ & 4.6 & $74(59)$ & 2.2 & $68(56)$ & 2.4 & $44(42)$ & 4.0 & $87(69)$ & 2.2 & $82(65)$ & 1.6 \\
\hline & 0.012 & $27(31)$ & 4.6 & $63(52)$ & 2.0 & $67(55)$ & 2.8 & $49(44)$ & 5.0 & $56(48)$ & 4.4 & $60(51)$ & 3.0 \\
\hline Significance & & (Ns) & $\mathrm{L}^{* * *}$ & (Ns) & NS & (NS) & NS & $\left(\mathrm{L}^{* * *}\right)$ & $\mathrm{Q}^{* *}$ & $\left(\mathrm{Q}^{* *}\right)$ & $\mathrm{L}^{\star * *}$ & $\left(\mathrm{Q}^{*}\right)$ & $\mathrm{L}^{* * *}$ \\
\hline \multirow[t]{4}{*}{3} & 0.0 & $32(35)$ & 3.4 & $57(49)$ & 3.0 & $54(47)$ & 4.2 & $53(47)$ & 2.0 & $83(66)$ & 2.0 & $75(60)$ & 1.6 \\
\hline & 0.003 & $15(22)$ & 5.0 & $74(60)$ & 2.6 & $48(44)$ & 5.0 & $43(41)$ & 5.0 & $53(47)$ & 5.0 & $80(63)$ & 1.8 \\
\hline & 0.006 & $18(25)$ & 4.8 & $74(59)$ & 2.0 & $45(42)$ & 5.0 & $52(46)$ & 4.0 & $79(63)$ & 2.0 & $81(64)$ & 1.6 \\
\hline & 0.012 & $14(22)$ & 5.0 & $70(57)$ & 3.0 & $49(45)$ & 4.6 & $61(51)$ & 3.8 & $63(53)$ & 3.8 & $56(48)$ & 2.6 \\
\hline Significance & & $\left(\mathrm{Q}^{\star *}\right)$ & $\mathrm{Q}^{\star \star *}$ & $\left(\mathrm{Q}^{* *}\right)$ & $\mathrm{Q}^{* * *}$ & $\left(\mathrm{Q}^{\star *}\right)$ & $\mathrm{Q}^{*}$ & $\left(\mathrm{Q}^{* *}\right)$ & $\mathrm{Q}^{* * *}$ & $\left(\mathrm{Q}^{\star \star}\right)$ & $\mathrm{Q}^{* *}$ & $\left(\mathrm{Q}^{\star * *}\right)$ & NS \\
\hline One-way LSD $_{0.05^{u}}$ & & $(6)$ & 0.6 & $(7)$ & 0.5 & $(4)$ & 0.6 & $(4)$ & 0.6 & $(7)$ & 0.6 & $(4)$ & 0.6 \\
\hline
\end{tabular}

${ }^{2} \mathrm{LF}$ and WR determined for $400 \mathrm{~cm}^{3}\left(24.4\right.$ inch $\left.^{3}\right)$ in 3.5 -inch-tall $\times 4.0$-inch-diameter $(8.89 \times 10.16-\mathrm{cm})$ pots.

'Substrates were dried back to $30 \%$ (wt:wt) moisture before testing with distilled water or APG/BLK added at each event.

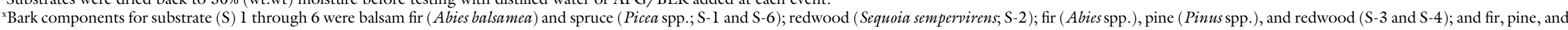




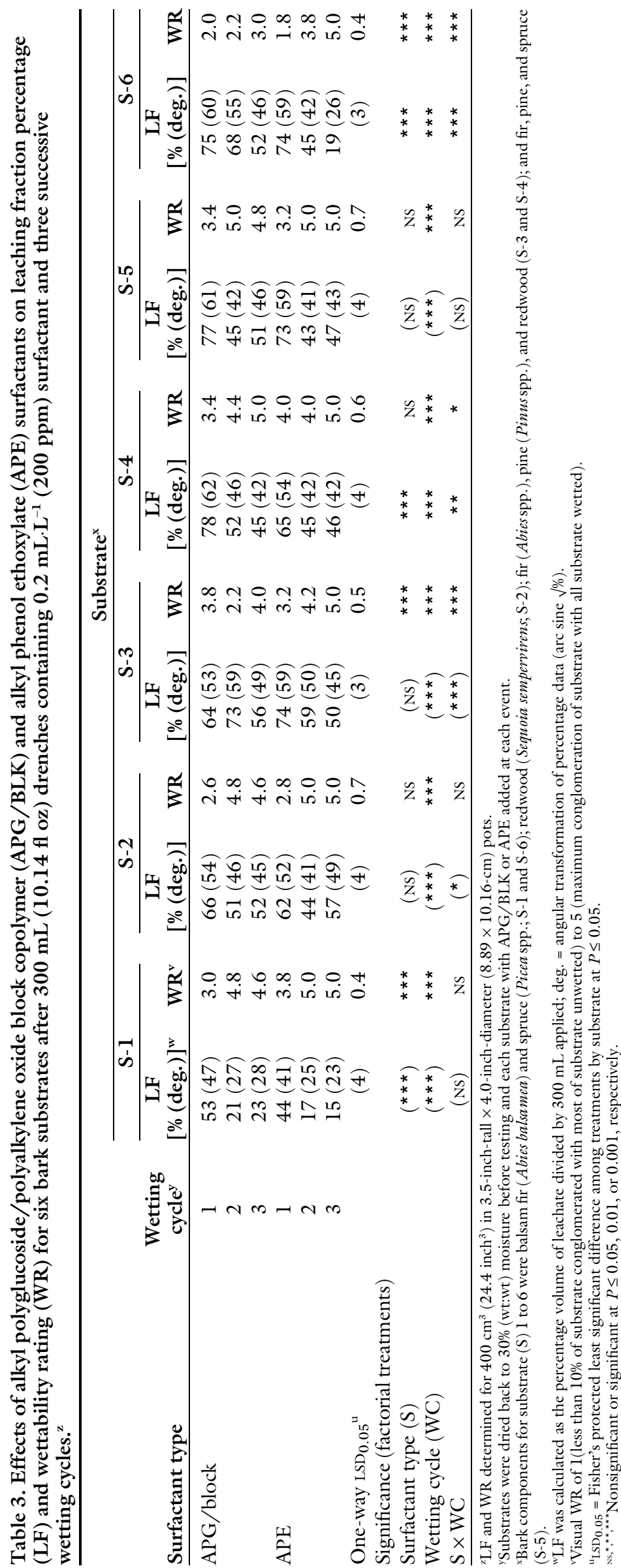

increased WR using $0.2 \mathrm{~mL} \cdot \mathrm{L}^{-1}$ APG/BLK or APE after two wetting cycles. APE-treated S-2 had reduced LF compared with APG/BLK-treated S-2 after two wetting cycles (Table 3).

This research evaluated a synergistic non-APE surfactant blend containing APG and BLK. Overall, the APG/BLK surfactant was not as effective as the APE surfactant, however, the APG/BLK surfactant was effective at reducing $\mathrm{LF}$ and increasing WR for most substrates tested. Thus, the APG/BLK surfactant offers a potential alternative to APE for some horticultural applications.

\section{Literature cited}

Airhart, D.L., N.J. Naturella, and F.A. Pokorny. 1978a. Influence of initial moisture content on the wettability of a milled pine bark medium. HortScience 13:432434.

Airhart, D.L., N.J. Natarella, and F.A. Pokorny. 1978b. The structure of processed pine bark. J. Amer. Soc. Hort. Sci. 103:404-408.

Airhart, D.L., N.J. Naturella, and F.A. Pokorny. 1980. Wetting a milled pine bark medium with surfactants. Forest Products J. 30:30-33.

Bilderback, T. 1993. Wetting agents and gels: Where they have a purpose. Comb. Proc. Int. Plant Prop. Soc. 43:421-423.

Bilderback, T.E. and M.R. Lotsheider. 1997. Wetting agents used in container substrates: Are they BMPs? Acta Hort. 450:313-320.

Blodgett, A.M., D.J. Beattie, J.W. White, and G.C. Elliott. 1993. Hydrophilic polymers and wetting agents affect absorption and evaporative water loss. HortScience 28:633-635

Cid-Ballarin, C., R. Munoz-Carpena, A. Soccorro-Monzon, and G. GomzalezTamargo. 1998. Wetting agent effects on peat properties related to nutrient solution losses and plant growth. Acta Hort. 458:161-169.

Czarnota, M. and P. Thomas. 2006. Using surfactants, wetting agents, and adjuvants in the greenhouse. Univ. of Georgia Coop. Ext. Bull. 1314. 4 May 2007. <http://pubs.caes.uga.edu/ caespubs/pubcd/B1319/B1319.html>.

Gomez, K.A. and A.A. Gomez. 1984. Statistical procedures for agricultural research, 2nd ed. Wiley, New York. 


\section{Technology and Product Reports}

Hepworth, P. 2006. Non-ionic surfactants, p. 133-152. In: R.J. Farn (ed.). Chemistry and technology of surfactants. Blackwell, Oxford, UK.

Karsa, D.R. 2006. What are surfactants? p. 1-23. In: R.J. Farn (ed.). Chemistry and technology of surfactants. Blackwell, Oxford, UK.

Pill, W.G., H.D. Tilman, and R.W. Taylor. 1995. Nitrogen-enriched ground kenaf (Hibiscus cannabinus L.) stem core as a component of soilless growth media. J. Hort. Sci. 70:673-681.

Rice, C., I. Schmitz-Afonso, J. LoyoRosales, E. Link, M. Thoma, E. Fay, D.
Altfater, and M. Camp. 2003. Alkylphenol and alkylphenol-ethoxylates in carp, water and sediment from Cuyahoga River, Ohio. Environ. Sci. Technol. 37:37473754 .

Templeton, A.R. 1999. Methods for decreasing hydrophobicity of peat, bark and rockwool in soilless mixes used for plant growth, promoting easier, faster and more even watering of such mixes without plant injury and providing activity for future watering. U.S. Patent 5,867,937 U.S. Patent and Trademark Office, Washington, DC.
Walden, R., K. Browne, and M. Olszewski. 2000. Determining the surfactant requirement of peat-based horticultural substrates. Proc. 1lth Int. Peat Congr. Vol. II. p. 1083. (Abstr.).

White, G.F. 1993. Bacterial biodegradation of ethoxylated surfactants. Pest. Sci. 37:159-166

Yelanich, M. and R.P. Vetanovetz. 2004. Plant growth media and processes for production thereof and compositions for use therein. U.S. Patent 6711850. U.S. Patent and Trademark Office, Washington, DC. 